\title{
Ownership Structure and Firm Performance: A Pragmatic Evidence From Pakistan
}

\author{
Naveeda Akhter Katper \\ Institute of Business Administration, Faculty of Commerce and Business Administration \\ University of Sindh, Allama I.I. Qazi Campus, 76080, Jamshoro, Pakistan
}

Vivake Anand (Corresponding author)

Department of Management Sciences Isra University, Hyderabad

E-mail: vivake.anand@isra.edu.pk

Abdul Subhan Kazi

Department of Management Sciences Isra University, Hyderabad

Received: Oct. 29, 2018 Accepted: Nov. 20, $2018 \quad$ Published: Dec. 21, 2018

doi:10.5296/ifb.v5i2.14090ＵRL: http://dx.doi.org/10.5296/ifb.v5i2.14090

\begin{abstract}
Agency theory suggests that allowing managers to participate in firm's ownership assists as an operative instrument to cut agency costs and augment performance of the firm. While the managerial ownership's role in corporate performance has been profoundly scrutinized for the firms in developed countries, there is a lack of such research, in black and white, on the non-financial firms in developing countries. The study aims seeks to inspect the impression of managerial ownership on the performance of Pakistani firms. This observational investigation endeavours to look for a connection between managerial ownership and firm execution on the 75 firms from 2009 to 2013 in Pakistan. Using panel data models, this study finds mixed results in different methods. We find no strong evidence for the managerial ownership as a significant determinant of the corporate performance for the given sample of Pakistani firms. Besides, the connection is vigorous to various procedures of firm.
\end{abstract}

Keywords: Firm performance, Managerial ownership, Pakistani firms 


\section{Introduction}

Agency theory proposes that the separation of ownership and management of the firm causes a serious agency problem. The agents or managers run a business on behalf of widely spread shareholders. This creates a typical agency related problem for the firms (Eisenhardt, 1989). The opportunistic behavior of managers exacerbates this problem when they settle on choices in their own particular advantages at the cost of investors' advantage (Jensen \& Meckling, 1976). However, agency theory proposes that the conflicts between directors of firm and owners could be determined if managers partially own the firm they run (Jensen \& Meckling, 1976). Therefore, managerial ownership is perceived to be one of the crucial factors of firm performance. Earlier work observes that the firm execution enhances when ownership and managerial stakes are fused through grouping of ownership (Agrawal \& Mandelker, 1990). The financial performance is one of the indicators of judging the performance of managers and their self-serving behavior (Hillman, Keim, \& Luce, 2001). In spite of the fact that there exists a huge assortment of research on the ownership-performance relationship in developed countries, yet there is a need to investigate this aspect in the developing countries like Pakistan.

Collecting the financial and accounting data from Pakistan for the period of five years, we discover the negative and significant connection between managerial ownership and firm performance in OLS regression, however, negative and insignificant reconnection through fixed-effect method. The regression findings do not corroborate the agency cost perspective that increasing managerial ownership aligns otherwise conflicting of managers' and shareholders' interest in the firms. With the inclusion of several control variables, our findings indicate that managers, with the varying equity level, behave indifferently for the corporate performance hence exerting no impact.

\section{Literature Review}

Since, Berle and Gardiner (1968) imply that diffused ownership adversely affects the firm performance. The seminal research concerning owner-manager relationship is led by Jensen and Meckling (1976). A good volume of research took place on the opportunistic managerial approach. Hence, various authors attempted to explore managerial self-interest pursuit in different ways (Bethel \& Liebeskind, 1993; Hoskisson, Johnson, \& Moesel, 1994). In this vein, the authors opine that the improvement takes place with the emergence of managerial interest by ownership concentration (Agrawal \& Mandelker, 1990). It is because key equity holders' build concentrated ownership and thus reduce the cost of the agency at considerably low level. Moreover, block holders may be opportunistically excerpt firms' resources for their personal assistances which exercise a contrary consequence on the firm's value.

In the literature, managerial ownership is observed as one of the factors of firm performance. Numerous authors have investigated the connection between firm performance and ownership structure whereas various authors find significant relationship in this connection (Demsetz, 1983; Demsetz \& Lehn, 1985; Kole, 1996). Despite a good volume of research, the findings are inconsistent leaving the room for further analysis on the connection between ownership and firm performance. In this framework, literature shows diverse studies finding 
mixed results hence the matter is unresolved as one cluster of studies finds a positive relationship. The other band of research discovers the negative relationship. However, the third and fourth groups observe curvilinear relationship and no connection between ownership and performance respectively.

Porta, Lopez - de - Silanes, Shleifer, and Vishny (2002) analysed the constructive outcome between ownership grouping and profitability. They argued that in the weak legal environment, the positive association between profitability and the ownership is greater. It is also projected that firms with healthier corporate governance and healthier investment opportunities should have a higher valuation. Numerous other works found a significant and positive connection between concentrated ownership and performance such as (Gedajlovic \& Shapiro, 2002; Kapopoulos \& Lazaretou, 2007). Hence, the studies show that having lucrative investment prospects, the regulatory shareholders divert to concentrated ownership resulting the higher firm value.

However, Cho and Kim (2007) examine the outcome of outside directors on firm performance in the Korean firms and find the mixed results. They observe a constructive connection between outside director efficiency (outside director participation rate) and firm profitability, however, a adverse moderating effect regarding large shareholder ownership and managerial ownership. Also, a constructive moderating effect when it comes to block holder ownership. They indicate that outside directors had a constructive but frail influence. Outside shareholders had weak and a smaller amount of power to screen large controlling shareholders. The same effect was found by Javid and Iqbal (2008) who explore the connection between ownership concentration and firm's performance and conclude that with increasing profitable opportunity, controlling equity holders distract to the concentration ownership and the firm value becomes high. Thus, they observe the positive effect on firms' profitability; nevertheless, they maintain the negative relation between corporate governance, disclosures and transparency with concentration of ownership.

On the other hand, Craswell, Taylor, and Saywell (1997) find a curvilinear relationship between insider ownership and corporate performance. However, the findings do not support the institutional ownership as an important determinant of Australian firms' performance. Moreover, it is also observed that the advanced firm success requires a less diffused ownership. Hence, some studies show that the managerial ownership is not a determining factor of firm performance such as Demsetz and Villalonga (2001) and Chang (2003)catch no evidence for the relationship between ownership and firm performance. They find no noteworthy connection between the two variables due to the distributed ownership supporting the idea that diffused ownership may not align the owner-manager interests. Hence, it may exaggerate some agency problems.

Convincingly, the available empirical research established on the connection between firm performance and ownership structure is still inadequate and incompatible. To see this problem from a different angle, we attempt to assess the managerial ownership and performance in Shariah-compliant firms. Based on our empirical evidence, we can infer managerial tendency to align the interest of stakeholders and reduce the agency problem. 
Since the managerial ownership is not directly investigated with firm performance in Shariah-compliant firms. Therefore, this research would be a new beginning in this area and contribute to literature as vital importance. This study is also useful for the practical purpose and will help stakeholders and investors in investing decisions.

\section{Hypothesis Development}

Based on agency separation hypothesis, we test the argument that managers have divergent motives which can affect firm performance (Jensen \& Meckling, 1976). More strikingly, the literature indicates that managerial discretion creates agency costs normally by two ways. First the managers are prone to engage themselves in such "short run cost-increasing activities" by which they scheme to upsurge their "nonsalary income", or to deliver other kind of "on-the-job consumption". This conduct leads to decline the firm profits by augmenting the costs. Second, managers tend to satisfy their power, prestige, and status needs (Baumol, 1959) and over-invest in long-run projects to exploit size and growth inspite of commercial profits (Jensen \& Warner, 1988). This is additionally watched that such self-interested maneuvering happens when directors over-broaden (diversify). In this situation, managers invest in negative NPV projects thus decreasing the firm profits. Though, short run cost increase and self-interest planning reveal two different routes, the both ways if managerial discretion exists, firm performance will decrease.

In the absence of managerial incentives and effective monitoring, discretionary behaviour among the management rises. Be that as it may, executive participation in corporate ownership would boost the executives to work in the general best advantages of the of the owners (Jensen \& Meckling, 1976). Based on this argument, following hypothesis is developed and tested.

\section{H0: The managerial ownership does not affect profitability of the firm.}

H1: The managerial ownership has a noteworthy outcome on the effectiveness of the firm.

\section{Data and Sample Size}

The main sources of data for this study comprise the financial statement data for the companies listed on Pakistan Stock Exchange. The data on balance sheet variables and income statement were extracted from the annually published financial statements of non-financial companies listed on Karachi Stock Exchange. The secondary data are published by the State Bank of Pakistan (SBP), the central bank of the country. This source is considered as one of the authoritative sources of data on Pakistani corporate sector. The publication tabulates yearly the most valuable data on each company listed on KSE. We extracted the ownership data of firms by locating each company's financial statements for each year of the sample period from their respective websites. In Pakistan, firms are required to publicize their pattern of shareholding in the annual report as per the basic requirements of the Securities and Exchange Commission of Pakistan (SECP), the watchdog for the corporate sector in Pakistan. We collected the firms that made a list for all the years that is from 2009 to 2013. This made our sample relatively more balanced. As balanced data records observations of the same unit every time, it reduces noise and heterogeneity normally observed in the 
unbalanced panel. Following this procedure, we collected the data for 75 firms from 2009 to 2013 for five years yielding our sample to more than 360 firm-year observations. We, however, were limited to the availability of ownership data; thus, we collected balanced panel data containing these firms.

\section{Model and Variables Description}

This section contains the model and definitions of variables. This study proposes the quantitative method of research and implies the econometric model. We use the following model to assess our hypothesis regarding the relationship between performance and managerial ownership following by some prior studies (Klein, Shapiro, \& Young, 2005). We developed two equations based on two different proxies for firm performance, Tobin's $Q$ and ROA. Equation (1) uses Tobin's Q as the dependent variable used by McConnell and Servaes (1990), and equation (2) applies returns on assets (ROA) as the dependent variable for the robustness check of results used by (Cui \& Mak, 2002; ZAMAN, 2011). The equations are given as below.

$$
\begin{gathered}
Q=\alpha_{0}+\beta_{1} \text { Managerial Ownership }_{i t}+\beta_{2} \text { Size }_{i t}+\beta_{3} \text { Tangibility }_{i t}+\beta_{4} \text { Leverage }_{i t}+ \\
\beta_{5} \text { Growth }_{i t}+\varepsilon_{i}
\end{gathered}
$$

$$
\begin{gathered}
\text { ROA }=\alpha_{0}+\beta_{1} \text { Managerial Ownership }_{i t}+\beta_{2} \text { Size }_{i t}+\beta_{3} \text { Tangibility }_{i t}+\beta_{4} \text { Leverage }_{i t} \\
+\beta_{5} \text { Growth }_{i t}+\varepsilon_{i}
\end{gathered}
$$

a) Firm performance: We use Tobin's $Q$ and ROA as the two main proxies for firm performance.

Following Klapper and Love (2004), Tobin's Q was computed as follows.

$$
Q_{i t}=\left(M V E_{i t}+T D_{i t}\right) /_{B V A_{i t}}
$$

Where $Q$ is Tobin's Q, MVE is the market value of equity, $T D$ is total debt, $B V A$ is book value of total assets, and $i$ and $t$ are firm and time subscripts. For the robustness, the dependent variable ROA is measured as the five-year mean return on assets which is used as an alternate measure to check the robustness of the results.

b) The explanatory variable: Managerial ownership is the main explanatory variable that is measured as a ratio of shares held by the management and a total number of equity shares.

c) The control variables: Managerial ownership is not the sole determinant of firm's profitability. Hence the literature identifies various other factors affecting the performance of the firm. The effect of these factors is, therefore, important to isolate. Following Cui and Mak (2002), we control for the effects of firm size, tangibility, leverage, and growth. All variables are defined in Table 1 below. 


\section{Il Macrothink}

Table 1. Description of variable

\begin{tabular}{ll}
\hline Variables & Measurement of variables \\
\hline $\begin{array}{l}\text { Dependent variable } \\
\text { Tobin's Q }\end{array}$ & $\begin{array}{l}\text { The ratio of market value of equity plus total debt to the book value of assets. } \\
\text { Return on Assets (ROA) }\end{array}$ \\
$\begin{array}{l}\text { Explanatory variable } \\
\text { Managerial Ownership (MO) }\end{array}$ & Fraction of managerial ownership in total equity, \\
$\begin{array}{l}\text { Control variables } \\
\text { Size (LNTA/SIZE) }\end{array}$ & Natural logarithm of total assets. \\
Tangibility (TANG) & Ratio of fixed assets to total assets, \\
Leverage (LEV) & Total debt to total asset ratio \\
Growth (GROW) & Annual \% change in sales \\
\hline
\end{tabular}

Source: Authors and Cui and Mak (2002).

\section{Results and Analysis}

Table 2 describes the descriptive statistics of the variables individually. We observe that the firm performance is 5.15 and 5.29 for $\mathrm{Q}$ and ROA respectively ranging from negative to positive profits indicating Tobin $\mathrm{Q}$ value relatively higher. The fraction of the concentration of managerial ownership is around $29 \%$ in our sample firms. These Pakistani firms have total assets of PKR 15206 million on average. The average tangibility is around $46.9 \%$ with the variation of $24 \%$. Whereas we notice that the mean debt ratio is around $25 \%$ with the variation of $32 \%$ and ranging from 0 to around $39 \%$. The mean of growth is however $63 \%$ fluctuating from negative to a positive value in the range.

Table 2. Descriptive statistics

\begin{tabular}{lccccc}
\hline Variable & Obs & Mean & Std. Dev. & Min & Max \\
\hline Q & 372 & 7.152 & 11.047 & -17.455 & 55 \\
ROA & 375 & 5.298 & 15.777 & -89.49 & 77.74 \\
MO & 375 & 28.729 & 27.963 & 0 & 93.11 \\
SIZE(PKR ml) & 375 & 1520.619 & 151.9 & 11.443 & 194475.6 \\
TANG & 375 & 0.469 & 0.242 & 0.002 & 1.868 \\
LEV & 375 & 0.253 & 0.326 & 0 & 0.3936 \\
GROW & 366 & 63.200 & 89.642 & -14.591 & 171.443 \\
\hline
\end{tabular}

Source: Author's own calculations.

\section{Correlation Analysis}

Table 3 presents the correlation for our sample firms. Managerial ownership is adversely linked with both Q and ROA. Managerial ownership does not envisage Q, however, Q is a 
adverse predictor of managerial ownership. Also, managerial ownership is negatively correlated with firm size, whereas, it is positively correlated with growth indicating that managers in firms with less assets and advanced growth rates hold more equity shares. This seems reliable with the evidence that stakes of managers are in line with those of owners for higher growth firms with the relatively lower assets base (Smith Jr \& Watts, 1992). ROA has a negative correlation with tangibility and leverage. The size is negatively associated with ROA, and similar correlation with Q depicting that large firms have a higher potential and the productive ability for future profitability growth. Larger firms may have more growth opportunities as compared to smaller firms. Moreover, firms in which assets base is higher, fixed assets ratio is lower, having a negative relationship between size and tangibility.

Table 3. Correlation matrix

\begin{tabular}{llllllll}
\hline & Q & ROA & MO & SIZE & TANG & LEV & GROW \\
\hline Q & 1 & & & & & & \\
ROA & $0.7204^{*}$ & 1 & & & & & \\
MO & -0.1471 & -0.0699 & 1 & & & & \\
SIZE & $-0.1494^{*}$ & $-0.1001^{*}$ & $-0.2072^{*}$ & 1 & & & \\
TANG & $-0.3944^{*}$ & $-0.2206^{*}$ & $0.1808^{*}$ & -0.0976 & 1 & & \\
LEV & $-0.2477^{*}$ & $-0.2951^{*}$ & 0.0351 & $-0.1851^{*}$ & 0.3105 & 1 & \\
GROW & -0.0711 & -0.0337 & $0.0716^{*}$ & -0.057 & $0.0857^{*}$ & 0.0716 & 1 \\
\hline
\end{tabular}

Source: Authors Calculation. ${ }^{*} \mathrm{p}<0.05 ; * \mathrm{p}<0.01$.

7.1 OLS Regression, Fixed Effect, and Random Effect Results: Dependent Variable Tobin's $Q$ and $R O A$

Pooled OLS, fixed effects, and random effects models are applied to examine the connection between managerial ownership and firm efficiency in Pakistani firms. In the first specification, Tobin's Q is used as the main proxy for firm efficeincy, and in second the ROA is the dependent variable. The results are reported in Table 4 and 5 respectively. The main explanatory variable of interest in the regression for our study is "managerial ownership" (MO). The Pooled OLS and fixed, and random effect models are run to test the hypothesis. The Haussmann test, when applied the fixed effect model, is shown as a better choice as a null hypothesis was rejected.

The OLS regression shows a negative/insignificant connection between managerial ownership and firm efficiency (performance) (Q), which is inconsistent with the hypothesis that firms performance enhances as a result of increased managerial ownership (Jensen \& Meckling, 1976). The outcomes are empirically similar to those found in earlier studies (Porta et al., 2002). However, our results in the fixed and random effect approach indicate that this relationship is negative and insignificant consistent with Demsetz and Villalonga (2001) and Chang (2003).

As for other explanatory variables, our outcomes show a mixed relationship between size and 


\section{Macrothink}

International Finance and Banking

ISSN 2374-2089

2018, Vol. 5, No. 2

firm efficiency. Our result turns into a different direction in the Pooled OLS method which is negative and significant, hence the mixed result is observed. The outcome here indicates that the firms rely on external funding more than the internal one which maintains that higher total assets may not necessarily lead to higher profits due to diseconomies of scales. The finding is also consistent with Craswell et al. (1997) and ZAMAN (2011) who examine that firm size is negatively correlated with profitability.

Nevertheless, it is observed that when there exists the economy of scale in large firms, there is expected a constructive connection between profitability and size (Baumol, 1959; Hall and Weiss, 1967; Shepherd, 1972; Markides, 1995). Following this, our study shows that the relationship between size and performance are positive and significant in fixed effect approach. Haussmann test indicates the fixed effect is the better choice according to which the results show the positive and substantial connection between size and efficiency. This outcome is reliable with the idea that organizations depend on inner resources more than the outer financing.

Table 4. Regression analysis of Tobin's Q on managerial ownership

The table reports the OLS, FE, and RE results of Eq. 1. The dependent variable is a return on assets (Tobin's Q). The explanatory variable is Managerial ownership (MO). The regression controls the effects of firm size (LNTA), tangibility (TANG), leverage (DAR), and growth (GROW). All variables are explained in Table 1.

\begin{tabular}{llll}
\hline Variables (ROE) & Pooled OLS & Fixed Effect & Random Effect \\
\hline MO & -0.049 & -0.005 & -0.010 \\
& $(2.66)^{* * *}$ & $(0.29)$ & $(0.56)$ \\
SIZE & -1.753 & 2.992 & 0.357 \\
& $(5.07)^{* * *}$ & $(3.56)^{* * *}$ & $(0.63)$ \\
TANG & -15.153 & -3.449 & -5.399 \\
& $(6.77)^{* * *}$ & $(2.08)^{* *}$ & $(3.33)^{* * *}$ \\
LEV & -5.978 & -6.41 & -7.100 \\
& $(3.67)^{* * *}$ & $(5.42)^{* * *}$ & $(6.15)^{* * *}$ \\
GROW & -0.000 & -0.000 & -0.000 \\
& $(0.73)$ & $(0.78)$ & $(0.79)$ \\
Constant & 41.658 & -37.078 & 4.319 \\
& $(7.50)^{* * *}$ & $(2.87)^{* * *}$ & $(0.49)$ \\
F/Wald test & 21.96 & 15.16 & $71.08 * * *$ \\
R_sq & 0.24 & 0.21 & 0.1815 \\
N & 363 & 363 & 363 \\
Hausman test & & & $38.53 * * *$ \\
P_value & & & $(0.000)$ \\
\hline
\end{tabular}

Source: Authors Calculation. ${ }^{*} \mathrm{p}<0.05 ; * * \mathrm{p}<0.01$. 


\section{Ml Macrothink}

International Finance and Banking

ISSN 2374-2089

2018, Vol. 5, No. 2

Our results show the negative and weighty connection between the coefficient of leverage and firm efficiency. One of the possible explanations for this relationship in Pakistani firms may be the underdeveloped financial bond market unlike developed countries. Consequently, the firms do not rely much on the debt financing like the firms in developed countries and having well-established bond markets. The rationality behind this phenomenon is when the firms utilize their retained earnings they save the cost of external financing thus by reducing the cost of capital firm's profitability increases and vice versa. Our findings are consistent with the results reported by Kapopoulos and Lazaretou (2007). However, our findings are contradictory to those by Craswell et al. (1997) who found a constructive connection between leverage and firm efficiency. The growth has a constructive and noteworthy connection with firm performance in both models which specifies that the firm performance also depends on the firm growth opportunities.

\subsection{Robustness Check}

To verify the robustness of our findings, we performed additional analysis replacing Tobin's $\mathrm{Q}$ with accounting measure of performance return on assets (ROA). Using penal regression, the Hausman test suggested the fixed effect method as an appropriate method so far. Hence, we find the consistent results in both equations on the measures of Q and ROA for the level of managerial ownership. The results, for equation 2 in which the ROA is a measure of dependent variable, are stated in the following table.

Table 5. Robustness check: regression analysis of ROA on managerial ownership

The table reports the OLS, FE, and RE results of Eq. 2. The dependent variable is a return on assets (ROA). The explanatory variable is Managerial ownership (MO). The regression controls the effects of firm size (LNTA), tangibility (TANG), leverage (DAR), and growth (GROW). All variables are explained in Table 1.

\begin{tabular}{llll}
\hline Variables (ROA) & Pooled OLS & Fixed Effect & Random Effect \\
\hline MO & -0.039 & -0.014 & -0.031 \\
& $(1.40)$ & $(0.20)$ & $(0.79)$ \\
SIZE & -1.934 & 7.343 & -1.420 \\
& $(3.70)^{* * *}$ & $(2.49)^{* *}$ & $(1.72)^{*}$ \\
TANG & -9.091 & 2.213 & -5.523 \\
& $(2.68)^{* * *}$ & $(0.38)$ & $(1.30)$ \\
LEV & -13.566 & -18.246 & -16.771 \\
& $(5.45)^{* * *}$ & $(4.36)^{* * *}$ & $(5.44)^{* * *}$ \\
GROW & -0.000 & -0.000 & -0.000 \\
& $(0.14)$ & $(0.16)$ & $(0.10)$ \\
Constant & 43.380 & -102.556 & 34.565 \\
& $(5.16)^{* * *}$ & $(2.26)^{* * *}$ & $(2.63)^{* * *}$ \\
F/Wald test & 11.86 & 6.96 & $39.45^{* * *}$ \\
R_sq & 0.14 & 0.11 & 0.70 \\
N & 366 & 366 & 366 \\
Hausman test & & & $13.92^{* * *}$ \\
& & & $(0.007)$ \\
\hline
\end{tabular}

$* \mathrm{p}<0.05 ; * *_{\mathrm{p}}<0.01$ 


\section{Conclusion}

Agency problem is a serious issue for the firms because it increases the costs of the firm. There is also a problem of the clash in the interest of different parties thus the alignment of interests among all stakeholders is a challenging task. Although a significant volume of research is conducted on the ownership structure and firm performance, however, still the issue seems inconsistent and unresolved. Therefore, this endavour is an attempt to scrutinize the behaviour of our sample of Pakistani firms to add the contribution to the body of literature. The research is conducted on the sample of around 75 non-financial firms covering five years from 2009 to 2013 in Pakistan. Our discoveries demonstrate that connection between firm's managerial ownership and firm efficiency is negative and significant in OLS however, negative and insignificant in fixed effect approach denying the impact of extent of managerial ownership on firm efficiency. For the set of control variables, the findings show a negative relationship between size and firm effectiveness. Moreover, the leverage is significantly and negatively related to firm effectiveness. Hence, it seems that Pakistani firms tend to depend on retained earnings and decrease the level of debt ratio with increasing firm performance that is steady with the idea of pecking order theory of capital structure.

\section{References}

Agrawal, A., \& Mandelker, G. N. (1990). Large shareholders and the monitoring of managers: The case of antitakeover charter amendments. Journal of Financial and Quantitative analysis, 25(2), 143-161. https://doi.org/10.2307/2330821

Baumol, W. J. (1959). Business behavior, value and growth.

Berle, A. A., \& Gardiner, C. (1968). Means. 1932. The modern corporation and private property, 204-205.

Bethel, J. E., \& Liebeskind, J. (1993). The effects of ownership structure on corporate restructuring. Strategic Management Journal, 14(S1), 15-31. https://doi.org/10.1002/smj.4250140904

Chang, S. J. (2003). Ownership structure, expropriation, and performance of group-affiliated companies in Korea. Academy of Management journal, 46(2), 238-253.

Cho, D. S., \& Kim, J. (2007). Outside directors, ownership structure and firm profitability in Korea. Corporate Governance: An International Review, 15(2), 239-250. https://doi.org/10.1111/j.1467-8683.2007.00557.x

Craswell, A. T., Taylor, S. L., \& Saywell, R. A. (1997). Ownership structure and corporate performance: Australian evidence. Pacific-Basin Finance Journal, 5(3), 301-323. https://doi.org/10.1016/S0927-538X(96)00028-5

Cui, H., \& Mak, Y. (2002). The relationship between managerial ownership and firm performance in high R\&D firms. Journal of corporate finance, 8(4), 313-336. https://doi.org/10.1016/S0929-1199(01)00047-5

Demsetz, H. (1983). The structure of ownership and the theory of the firm. The Journal of 
Law and Economics, 26(2), 375-390. https://doi.org/10.1086/467041

Demsetz, H., \& Lehn, K. (1985). The structure of corporate ownership: Causes and consequences. Journal of political economy, 93(6), 1155-1177. https://doi.org/10.1086/261354

Demsetz, H., \& Villalonga, B. (2001). Ownership structure and corporate performance. Journal of corporate finance, 7(3), 209-233. https://doi.org/10.1016/S0929-1199(01)00020-7

Eisenhardt, K. M. (1989). Agency theory: An assessment and review. Academy of management review, 14(1), 57-74. https://doi.org/10.5465/amr.1989.4279003

Gedajlovic, E., \& Shapiro, D. M. (2002). Ownership structure and firm profitability in Japan. Academy of Management journal, 45(3), 565-575.

Hillman, A. J., Keim, G. D., \& Luce, R. A. (2001). Board composition and stakeholder performance: Do stakeholder directors make a difference? Business \& Society, 40(3), 295-314. https://doi.org/10.1177/000765030104000304

Hoskisson, R. E., Johnson, R. A., \& Moesel, D. D. (1994). Corporate divestiture intensity in restructuring firms: Effects of governance, strategy, and performance. Academy of Management journal, 37(5), 1207-1251.

Javid, A. Y., \& Iqbal, R. (2008). Ownership concentration, corporate governance and firm performance: Evidence from Pakistan. The Pakistan Development Review, 643-659. https://doi.org/10.30541/v47i4IIpp.643-659

Jensen, M. C., \& Meckling, W. H. (1976). Theory of the firm: Managerial behavior, agency costs and ownership structure. Journal of financial economics, 3(4), 305-360. https://doi.org/10.1016/0304-405X(76)90026-X

Jensen, M. C., \& Warner, J. B. (1988). The distribution of power among corporate managers, shareholders, and directors. Journal of financial economics, 20, 3-24. https://doi.org/10.1016/0304-405X(88)90038-4

Kapopoulos, P., \& Lazaretou, S. (2007). Corporate ownership structure and firm performance: evidence from Greek firms. Corporate Governance: An International Review, 15(2), 144-158. https://doi.org/10.1111/j.1467-8683.2007.00551.x

Klapper, L. F., \& Love, I. (2004). Corporate governance, investor protection, and performance in emerging markets. Journal of corporate finance, 10(5), 703-728. https://doi.org/10.1016/S0929-1199(03)00046-4

Klein, P., Shapiro, D., \& Young, J. (2005). Corporate governance, family ownership and firm value: the Canadian evidence. Corporate Governance: An International Review, 13(6), 769-784. https://doi.org/10.1111/j.1467-8683.2005.00469.x

Kole, S. (1996). Managerial ownership and firm performance: incentives or rewards?

McConnell, J. J., \& Servaes, H. (1990). Additional evidence on equity ownership and 
corporate value. Journal of financial economics, 27(2), 595-612. https://doi.org/10.1016/0304-405X(90)90069-C

Porta, R., Lopez-de-Silanes, F., Shleifer, A., \& Vishny, R. (2002). Investor protection and corporate valuation. The journal of finance, 57(3), 1147-1170. https://doi.org/10.1111/1540-6261.00457

Smith Jr, C. W., \& Watts, R. L. (1992). The investment opportunity set and corporate financing, dividend, and compensation policies. Journal of Financial Economics, 32(3), 263-292. https://doi.org/10.1016/0304-405X(92)90029-W

ZAMAN, S. J. J. A. K. (2011). Determinants of bank profitability in Pakistan: Internal factor analysis. Journal of Yaşar University, 6(23), 3794-3804.

\section{Copyrights}

Copyright for this article is retained by the author(s), with first publication rights granted to the journal.

This is an open-access article distributed under the terms and conditions of the Creative Commons Attribution license (http://creativecommons.org/licenses/by/4.0/). 